\title{
Analysis on the Use of Continuous Improvement, Technology and Flipped Classroom in the Teaching- Learning Process by means of Data Science
}

\author{
Ricardo-Adán Salas-Rueda \\ La Salle University, MEXICO \\ (D) 0000-0002-4188-4610 SC 57190010006 \\ ricardoadansalasrueda@hotmail.com ricardo.salas@ulsa.mx
}

\begin{abstract}
ARTICLE INFO
Received: 8 June 2018

Accepted: 25 October 2018

Published: 12 November 2018

DOI: https://doi.org/10.12973/ojcmt/3955

ABSTRACT

This mixed research uses the Juran's methodology to achieve continuous improvement in the teaching-learning process on mathematics through technology. This study proposes the creation of a virtual environment by means of the FreeDFD simulator, flipped classroom and YouTube videos with the purpose of linking the theoretical topics in the Logical of Predicates Unit with the field of computer science. The variables related to the teaching-learning process are Efficiency (assimilation of knowledge) and Technical Quality (Bloom's Taxonomy: Memory, Comprehension and Application). On the other hand, students' perception is analyzed through the Quality of service (teaching-learning process, technological ability and mathematical ability) and Customer satisfaction (utility, benefits and need). By means of data mining (decision trees technique), this research identifies four predictive models on assimilation of knowledge considering Bloom's Taxonomy. The results obtained from linear regression (machine learning with $50 \%$ training and 50\% evaluation) indicate that the Juran's methodology facilitates the construction of virtual educational spaces through the stages related to the identification of clients, establishment of customer needs, translation of needs into the language of the organization, development of the product or service, creation of a process and transfer of the process to the operation. In conclusion, universities should improve educational conditions considering aspects of the technology, flipped classroom and continuous improvement.
\end{abstract}

Keywords: continuous improvement, ICT, higher education, flipped classroom, data science, data mining, learning machine

\section{INTRODUCTION}

Nowadays, universities are looking for new alternatives and strategies to improve the quality of higher education through the analysis and evaluation of the service provided (Salazar \& Cabrera, 2016; Tartaglia \& Walker, 2015). In fact, quality seeks to satisfy the needs and expectations of consumers (Fernández, González, Fernández, \& Segura, 2010; Lizarzaburu, 2016; Salas, 2018) in various sectors such as education (Bryant, 2013; Maffini \& Toth, 2017; Salas \& Vázquez, 2017; Treagust, Won, Petersen, \& Wynne, 2015), health (Alexander, Weiner, Shortell, \& Baker, 2007), logistics (He, Xu, Xu,\& Wu, 2016) and production (Chang, 2017). 
R.-A. Salas-Rueda

\begin{tabular}{lll}
\hline Table & 1. Evolution of quality & \\
\hline Item & Stages of quality & Description \\
\hline 1 & Inspection & Detect errors \\
2 & Quality control & Measure the variation of a process \\
3 & Quality assurance & Comply with the requirements established for the product or service \\
4 & Total quality management & Uses continuous quality improvement to satisfy the customer \\
\hline \multicolumn{2}{l}{ Source: } & Lizarzaburu, 2016 \\
\end{tabular}

In Mexico, the Education Sector Program 2013-2018 establishes that quality and equity play a fundamental role in achieving the efficient transformation of the teachinglearning process (Peralta, 2016). In particular, continuous improvement allows educational institutions to establish new forms of work in order to achieve efficiency (Salazar \& Cabrera, 2016).

The improvement of processes in educational institutions favors the use of new teaching-learning strategies through digital tools (Colmenares, 2010; Salas \& Salas, 2018). For example, the flipped classroom consists of planning various educational activities before and after face-to-face sessions in order to achieve meaningful learning during class time (Blau \& Shamir, 2017; Chen, Wang, Kinshuk, \& Chen, 2014).

By using Information and Communication Technologies (ICT) in the classroom, students acquire new skills related to knowledge acquisition, critical thinking and teamwork (Vázquez, López, \& Jaén, 2017). Also Burgi and Peralta (2011) explain that research on educational quality is mainly related to teaching-learning processes and school organization.

In the 21st century, teachers are facing new challenges to improve the educational process (Mamghani, Mostowfi, \& Khorram, 2018; Salas, Vázquez, \& Lugo, 2016). In fact, information and communication tools are more accessible to students. Therefore, teachers have the opportunity to innovate teaching-learning activities through technology (Wondemtegegn, 2018). For example, the incorporation of mobile phones in the educational field represents a creative and innovative strategy to facilitate the learning (Halder, Halder, \& Guha, 2015).

In particular, this mixed research analyzes the use of the Juran's methodology to achieve continuous improvement in the educational process on mathematics through the FreeDFD simulator, flipped classroom and YouTube videos.

\section{CONTINUOUS IMPROVEMENT IN ORGANIZATIONS}

Globalization is driving institutions to improve products and services offered to consumers (Carreño, 2009). Organizations have used different criteria and quality standards based on the efficiency of the processes with the purpose of guaranteeing the continuous improvement (García, Quispe, \& Ráez, 2003).

According to Peralta (2016, p.110), the total quality is "the progressive improvement in the way things are done, even when they have been made without errors, which focuses on permanent improvement". For example, ISO 9004: 2001 establishes the importance of understanding the current and future needs of customers to identify, implement and manage quality (García, Quispe, \& Ráez, 2003).

The concept of quality in organizations has undergone various modifications over time (Lizarzaburu, 2016). Table 1 shows the evolution of quality.

According to García, Quispe and Ráez (2003), the ISO 9004: 2001 standard establishes that continuous improvement is achieved through the following aspects: 
1. Analysis and evaluation of the existing situation

2. Objectives for improvement

3. Implementation of possible solution

4. Measurement, verification, analysis and evaluation of the results on the implementation

5. Formalization of changes

Several authors (e.g., García, Quispe \& Ráez, 2003) explain that the continuous improvement PDCA cycle uses the stages of Plan, Do, Check and Act in order to achieve quality in the processes. Also, Deming, Crosby, Ishikawa and Juran establish that quality is a means to achieve efficiency in organizations through productivity and competitiveness (Carreño, 2009).

For example, Ishikawa establishes the steps to achieve process improvement, that is, identification of the actual process, measurement and analysis of the process, identification of opportunities for improvement, normalization of the process and revision of the plan (Vasquez, 2016).

According to Cantú (2001), the planning on the quality proposed by Juran allows to achieve continuous improvement through the following aspects:

- Identification of clients

- Determine customer needs

- Translate needs into the language of the organization

- Develop products or services with characteristics that respond optimally to the needs of customers

- Develop a process capable of producing the characteristics of the product or service

- Transfer the process to the operation

This mixed research proposes the use of the FreeDFD simulator, flipped classroom and YouTube videos in order to update the teaching-learning process on predicate logic through the implementation of the Juran's methodology.

Therefore, the research questions are:

- What is the impact of the FreeDFD simulator, flipped classroom and YouTube videos in the teaching-learning process on predicate logic (learning machine with $50 \%$ training and $50 \%$ evaluation)?

- What is the perception of the students about the incorporation of technology in the teaching-learning process on the logic of predicates?

- What are the factors that influence the assimilation of knowledge on predicate logic considering data mining (decision trees technique)?

\section{METHOD}

This quantitative and qualitative research analyzes the impact of the FreeDFD simulator, flipped classroom and YouTube videos in the teaching-learning process on the predicate logic considering the Juran's methodology and data science. The sample is composed of 20 students of the Bachelor in Business Management and Information Technology who studied the Computational Mathematics course at a Mexican University during the 2017 school year. 
R.-A. Salas-Rueda

Table 2. Planning of the Logical of Predicates Unit

Stage Juran's methodology

Description

1 Identification of the clients

Students take the subject Computational Mathematics during the third semester of the Degree in Business Management and Information Technology

2

Determine customer needs

The students of the Degree in Business Management and Information Technology demand the use of digital tools to link theoretical knowledge with reality

Translate needs into the language of Logical of Predicates Unit includes the topics on Categorical the organization

Propositions (universal and existential quantifiers) and Reasoning (demonstration by induction), which is linked to the field of computer science.

$4 \quad$ Develop products or services with characteristics that respond optimally to the needs of customers

The FreeDFD simulator, flipped classroom and YouTube videos allow the construction of dynamic and interactive spaces

$5 \quad$ Develop a process capable of to facilitate the application of theoretical concepts with reality product or service

Through the FreeDFD simulator, flipped classroom and the topics of Categorical Propositions and Reasoning

6 Transfer the process to the operation

During the Logical of Predicates Unit, the students perform various laboratory practices through the FreeDFD simulator

\section{Procedure}

This mixed research is based on Juran's ideas about continuous improvement to improve the teaching-learning process in the Logical of Predicates Unit through ICT (See Table 2).

Through the stages of the Juran's methodology, this mixed study proposes the construction of a virtual learning space by means of the FreeDFD simulator, flipped classroom and YouTube videos in order to link the theoretical topics on the Logic of predicates with the field of computer science.

The procedure began with the organization and creation of laboratory practices on the topics of Categorical Propositions (universal and existential quantifiers) and Reasoning (demonstration by induction). The FreeDFD simulator allows students to apply the contents on quantifiers and demonstration by induction in the field of computer science.

In fact, the Juran's methodology allowed updating the teaching-learning activities on the logic of predicates through the flipped classroom:

1. Activities before class: Review YouTube videos about the use of the FreeDFD simulator

2. Class activities: Perform exercises on the topics of Categorical Propositions (universal and existential quantifiers) and Reasoning (demonstration by induction)

3. Activities after class: Perform laboratory practices through the FreeDFD simulator

Also, the programming topics on the conditional structures (simple and multiple) and iterative structures (for and while) are used in the Logical of Predicates Unit with the purpose of simulating the operation of the quantifiers and the demonstration by induction.

The laboratory practices carried out in the Logical of Predicates Unit are:

- Practice 1: Use of universal quantifier and condition structure

- Practice 2: Use of the quantifier and the iteration structure

- Practice 3: Use of quantifier, condition structure and iteration structure 


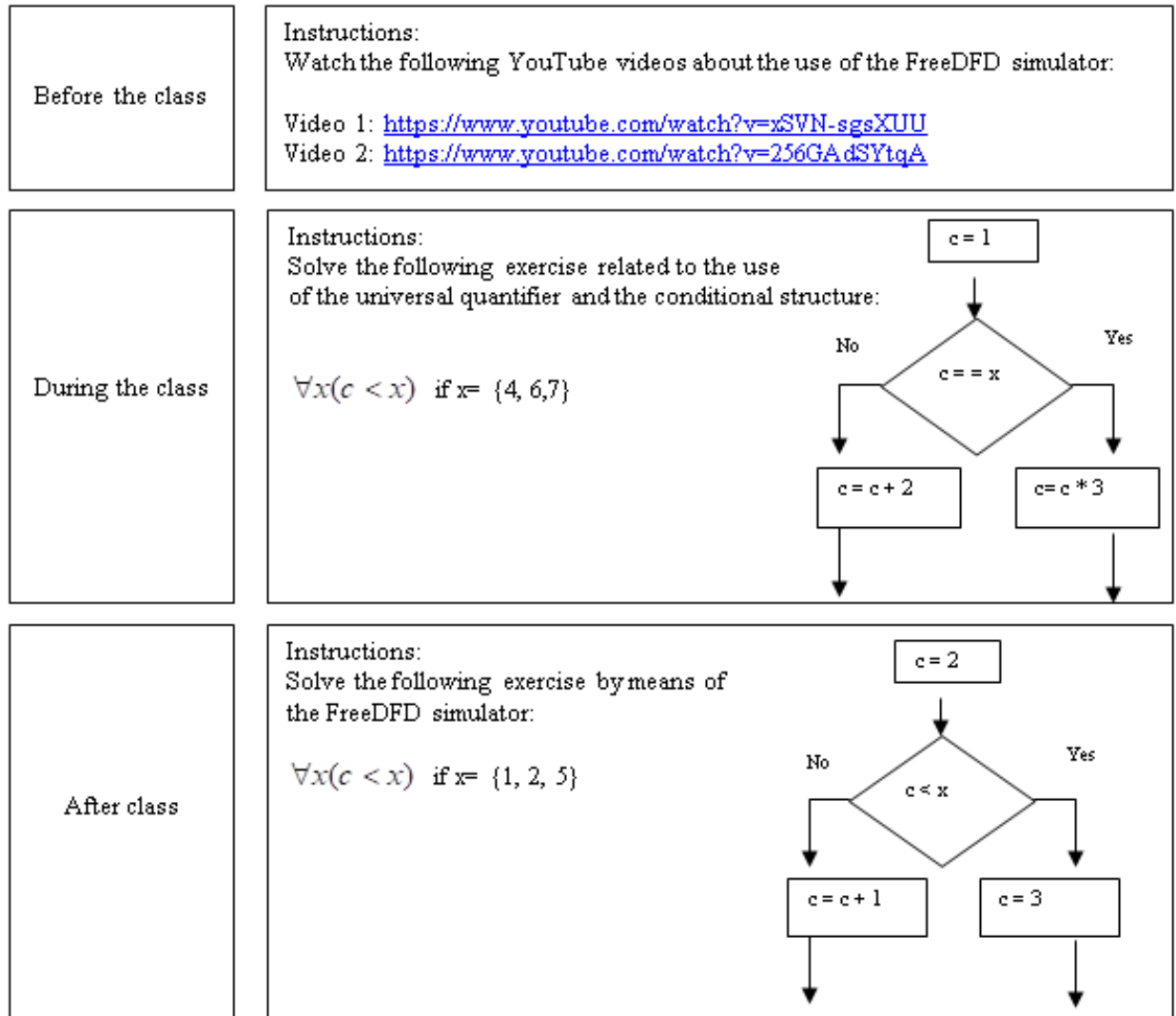

Figure 1. Continuous improvement in the Logical of Predicates Unit

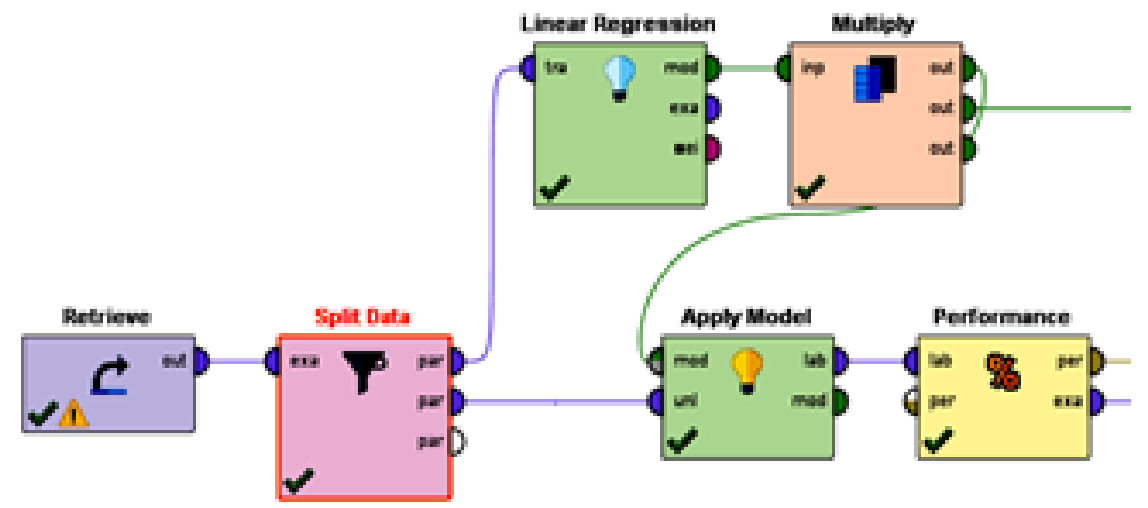

Figure 2. Use of the Rapidminer tool for learning machine

- Practice 4: Demonstration by induction

Figure 1 shows an example of the teaching-learning activities carried out by the students of the Computational Mathematics course.

This research uses the Rapidminer tool to identify predictive models (decision tree technique) and determine the impact of FreeDFD simulator, flipped classroom and YouTube videos on the educational process through machine learning (50\% of training and $50 \%$ of evaluation).

Figure 2 shows the use of the Rapidminer tool to calculate learning machine (linear regression). The Split Data component allows establishing 50\% of training and 50\% of evaluation.

The hypotheses of this study related to the use of technology and the teaching-learning process are: 


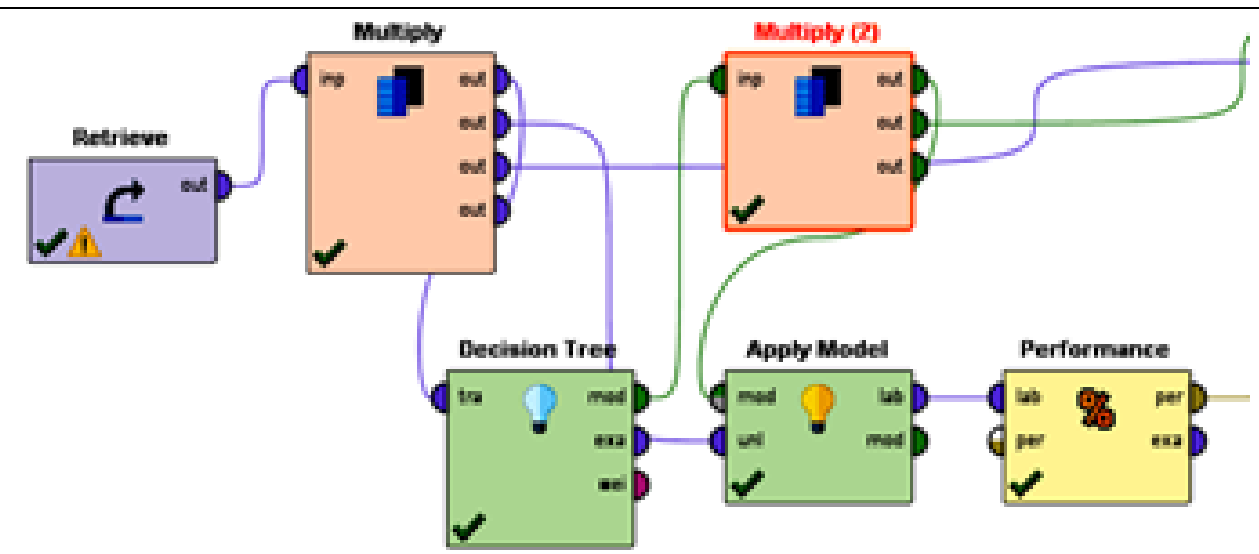

Figure 3. Use of the RapidMiner tool

\begin{tabular}{|l|l|l|l|l|l|}
\hline Row No. & Application L & Gender & Age & Grade & Simple cond._. \\
\hline 1 & Quile & Fermale & 19 & 10 & Quite \\
\hline 2 & Quile & Male & 20 & 9.700 & Quile \\
\hline 3 & Totally & Female & 19 & 10 & Totally \\
\hline 4 & Tokally & Female & 19 & 10 & Totally \\
\hline
\end{tabular}

Figure 4. Information for the Predictive Model 1

- H1: The use of the FreeDFD simulator, flipped classroom and YouTube videos positively influences the grade of the first partial during the assimilation of the Simple conditional structure

- H2: The use of the FreeDFD simulator, flipped classroom and YouTube videos have a positive influence on the grade of the first partial during the assimilation of the Multiple conditional structure

- H3: The use of the FreeDFD simulator, flipped classroom and YouTube videos positively influences the grade of the first partial during the assimilation of the For iterative structure

- H4: The use of the FreeDFD simulator, flipped classroom and YouTube videos have a positive influence on the grade of the first partial during the assimilation of the While iterative structure

Figure 3 shows the components of the RapidMiner tool used for the creation of the following predictive models of the Assimilation of knowledge through the decision trees technique:

- Predictive Model 1: Assimilation of knowledge model about Simple conditional structure

- Predictive Model 2: Assimilation of knowledge model about Multiple conditional structure

- Predictive Model 3: Assimilation of knowledge model about For iterative structure

- Predictive Model 4: Assimilation of knowledge model about While iterative structure

Through the RapidMiner tool, this research identified the elements that influence the assimilation of knowledge on predicate logic considering the Student profile. For example, Figure 4 shows the information used for the construction of Predictive Model 1. 
Online Journal of Communication and Media Technologies, 2018

\begin{tabular}{|l|l|l|l|l|l|}
\hline Row Mo. & Application L & Gender & Age & Grade & Multiple con__ \\
\hline 1 & Quite & Fernale & 19 & 10 & Quite \\
\hline 2 & Quite & Male & 20 & 9.700 & Quite \\
\hline 3 & Totally & Female & 19 & 10 & Totally \\
\hline 4 & Totally & Female & 19 & 10 & Totally \\
\hline
\end{tabular}

Figure 5. Information for the Predictive Model 2

\begin{tabular}{|l|l|l|l|l|l|}
\hline Row No. & Application L. & Gender & Age & Grade & For iterative - \\
\hline 1 & Quite & Female & 19 & 10 & Ouite \\
\hline 2 & Quite & Male & 20 & 9.700 & Regular \\
\hline 3 & Totally & Fernale & 19 & 10 & Totally \\
\hline 4 & Totally & Female & 19 & 10 & Totally \\
\hline
\end{tabular}

Figure 6. Information for the Predictive Model 3

\begin{tabular}{|l|l|l|l|l|l|}
\hline Row Ha. & Application L. & Gender & Age & Grade & While iterati.. \\
\hline 1 & Quile & Female & 19 & 10 & Quite \\
\hline 2 & Quite & Male & 20 & 9.700 & Quite \\
\hline 3 & Totally & Female & 19 & 10 & Totally \\
\hline 4 & Totally & Female & 19 & 10 & Totally \\
\hline
\end{tabular}

Figure 7. Information for the Predictive Model 4

Figure 5 shows the information used to build the Predictive Model 2 through the Rapidminer tool.

Figure 6 shows the information used to create the Predictive Model 3 through the decision tree technique.

Figure 7 shows the information for the construction of the Predictive Model 4.

Data Collection

After completing the Logical of Predicates Unit, the Measurement Instrument is applied to the students of the Computational Mathematics course (See Table 3). 
R.-A. Salas-Rueda

\begin{tabular}{lll}
\hline Table 3. Measurement instrument \\
\hline Item & Variable & Dimension \\
\hline 1 & Student profile & Gender \\
& Age \\
& Bachelor's degree \\
& Grade of the first partial \\
\hline 2 & Efficiency & Assimilation of knowledge about Simple conditional structure \\
& & Assimilation of knowledge about Multiple conditional structure \\
& & Assimilation of knowledge about For iterative structure \\
& Assimilation of knowledge about While iterative structure \\
\hline 3 & Technical quality & Memory level about Simple conditional structure \\
& (Taxonomy of Bloom) & Memory level about Multiple conditional structure \\
& & Memory level about For iterative structure \\
& Memory level about While iterative structure \\
& Level of understanding about Simple conditional structure \\
& Level of understanding about Multiple conditional structure \\
& Level of understanding about For iterative structure \\
& Level of understanding about While iterative structure \\
& Application level about Simple conditional structure \\
& Application level about Multiple conditional structure \\
& Application level about For iterative structure \\
& Application level about While iterative structure \\
\hline 5 & Customer satisfaction & Teaching-learning process \\
& & Technological skills \\
& Mathematical skills \\
\hline & Nenefits \\
& &
\end{tabular}

\section{Analysis of Data}

The Rapidminer tool enabled the analysis of data with the purpose of identifying predictive models (decision tree technique) and determining the impact of FreeDFD simulator, flipped classroom and YouTube videos in the educational process through learning machine (50\% of training and $50 \%$ evaluation).

\section{RESULTS}

This research presents the results on data science, the use of the FreeDFD simulator, flipped classroom and YouTube videos in the educational process and the perceptions of the students.

\section{Data Science}

Figure 8 shows the Predictive Model 1. For example, if the student considers that FreeDFD simulator, flipped classroom and YouTube videos totally facilitates the assimilation of the Simple conditional structure and is less than and equal to 21 years old then school activities (before, during and after the face-to-face session) totally facilitate the application of the topics on the Simple conditional structure. 


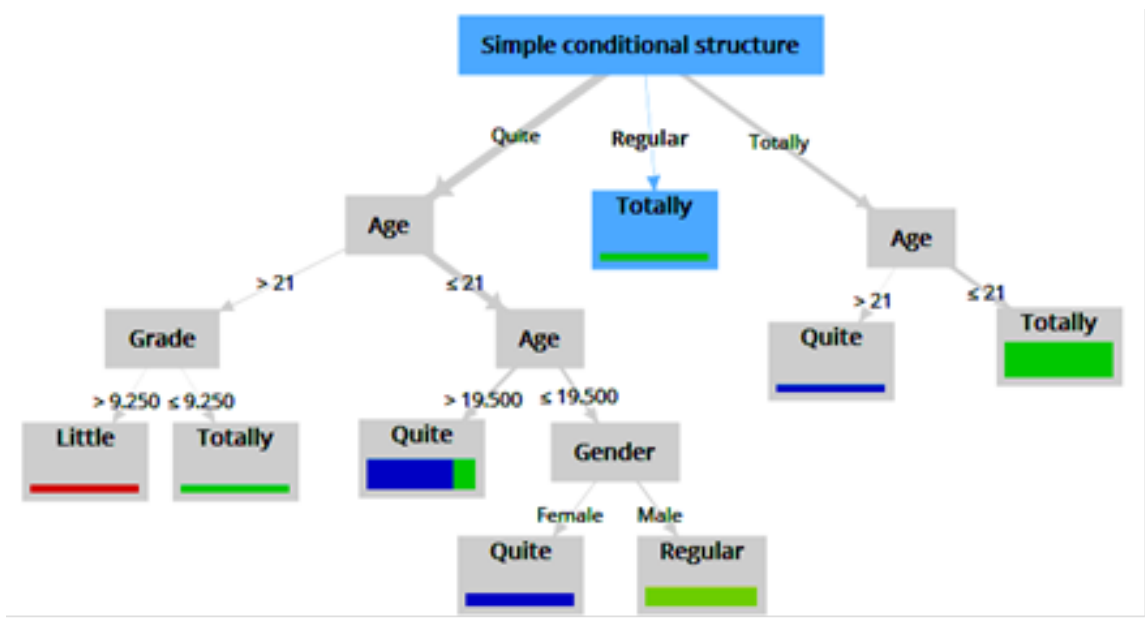

Figure 8. Predictive Model 1

\begin{tabular}{|c|c|c|c|c|c|}
\hline & true Culb & true Totaly & true Regular & true Lette & dass predision \\
\hline pred Quite & 7 & 1 & 0 & 0 & $8750 \mathrm{x}$ \\
\hline pred Totally & 0 & 8 & 0 & 0 & $100.00 \%$ \\
\hline pred Regular & 0 & 0 & 3 & 0 & $100.00 \%$ \\
\hline pred utee & 0 & 0 & 0 & 1 & $10000 \%$ \\
\hline dass recall & $100.00 \mathrm{x}$ & 8B.89\% & $10000 \%$ & $100.00 \%$ & \\
\hline
\end{tabular}

Figure 9. Accuracy of Predictive Model 1

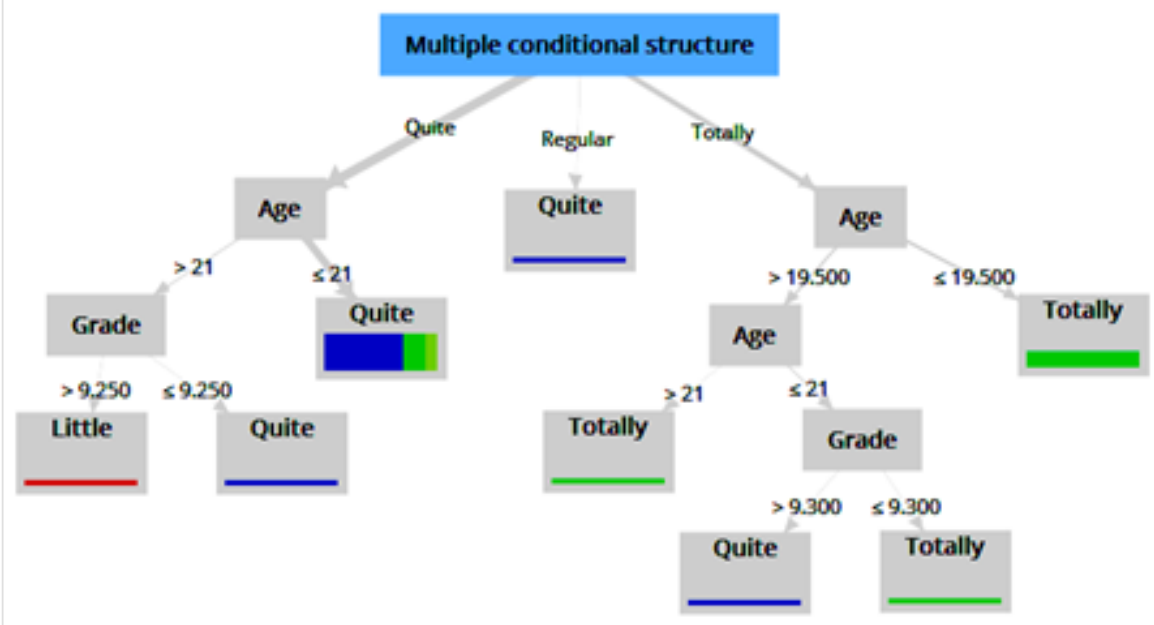

Figure 10. Predictive Model 2

The accuracy of Predictive Model 1 is $95.00 \%$ (See Figure 9).

Figure 10 shows the Predictive Model 2. For example, if the student considers that FreeDFD simulator, flipped classroom and YouTube videos totally facilitates the assimilation of the Multiple conditional structure and has an age less than and equal to 19.5 years old then school activities (before, during and after the face-to-face session) totally facilitate the application of the topics about the Multiple conditional structure.

The accuracy of Predictive Model 2 is $85.00 \%$ (See Figure 11). 


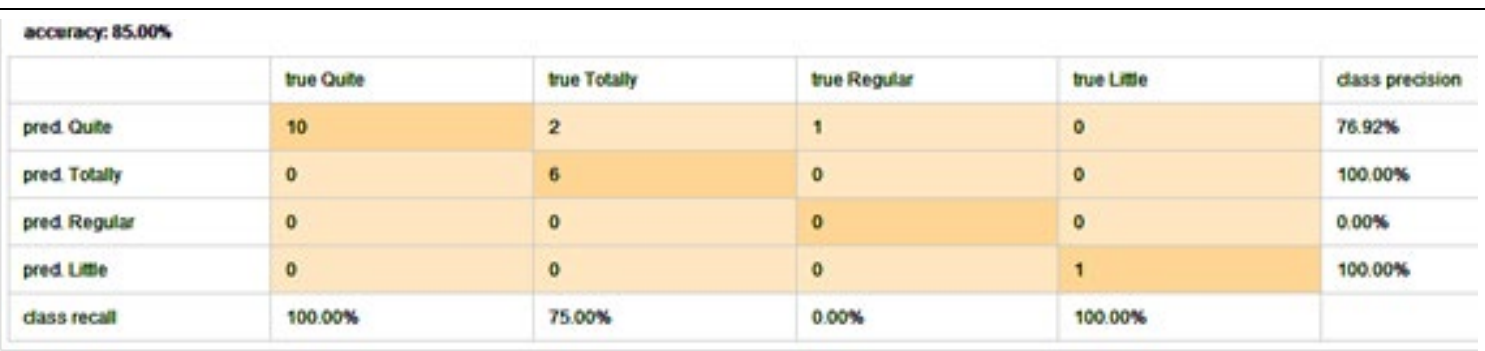

Figure 11. Accuracy of Predictive Model 2

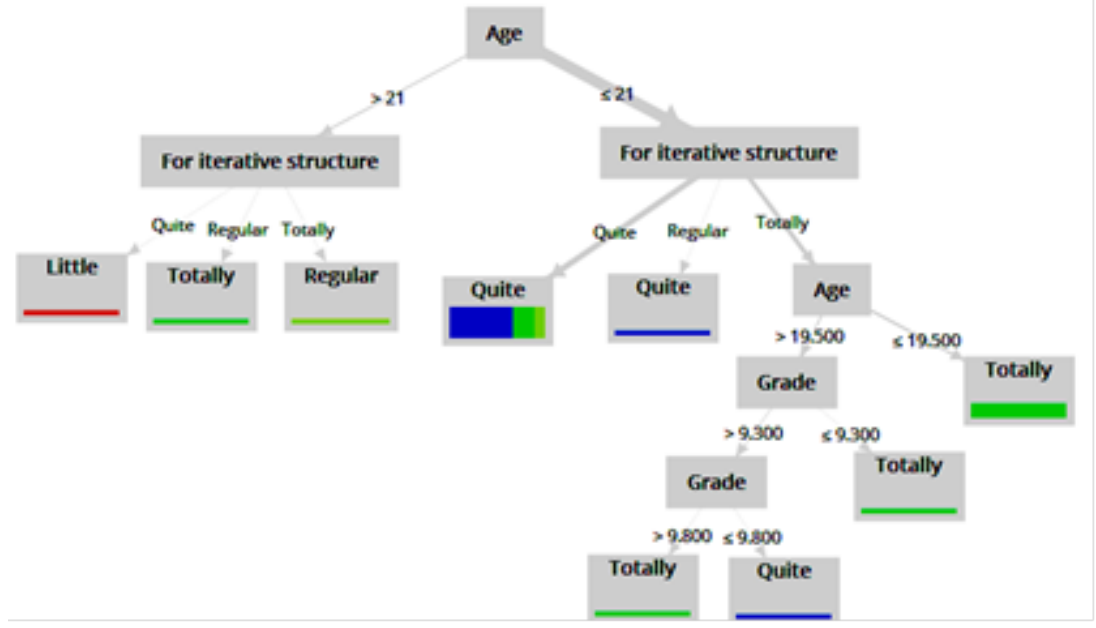

Figure 12. Predictive Model 3

\begin{tabular}{|c|c|c|c|c|c|}
\hline & true Culte & true Totally & true Regular & true Late & dass predision \\
\hline pred Culte & 8 & 2 & 1 & 0 & $7273 \%$ \\
\hline pred Totally & 0 & 7 & 0 & 0 & $100.00 \%$ \\
\hline pred Regular & 0 & 0 & 1 & 0 & $100.00 \%$ \\
\hline pred Litte & 0 & 0 & 0 & 1 & $100.00 \%$ \\
\hline dass recall & $100.00 \%$ & $77.78 \%$ & $50.00 \%$ & $100.00 \%$ & \\
\hline
\end{tabular}

Figure 13. Accuracy of Predictive Model 3

Figure 12 shows the Predictive Model 3. For example, if the student considers that FreeDFD simulator, flipped classroom and YouTube videos totally facilitates the assimilation of the For the iterative structure and has an age less than and equal to 19.5 years old then school activities (before, during and after the face-to-face session) totally facilitate the application of the topics on the For iterative structure.

The accuracy of Predictive Model 3 is $85.00 \%$ (See Figure 13).

Figure 14 shows the Predictive Model 4. For example, if the student considers that FreeDFD simulator, flipped classroom and YouTube videos totally facilitates the assimilation of the While iterative structure then school activities (before, during and after the face-to-face session) totally facilitate the application of the topics on the While iterative structure. 


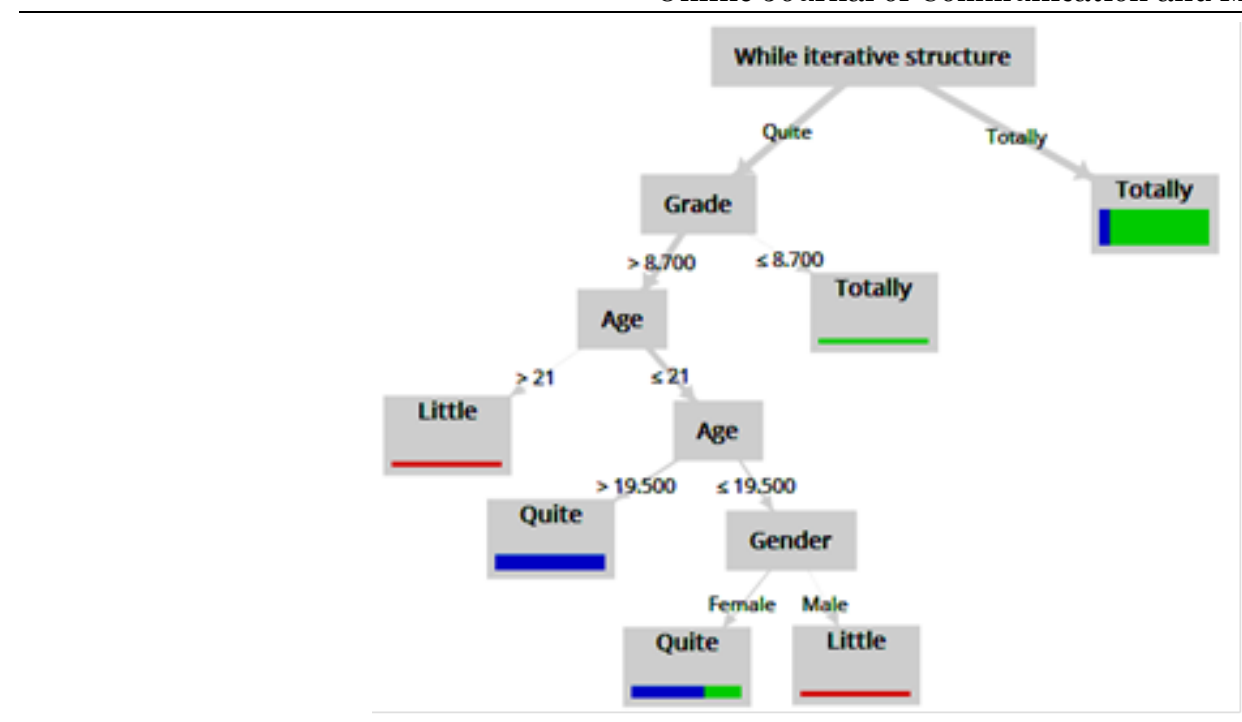

Figure 14. Predictive Model 4

\begin{tabular}{|c|c|c|c|c|}
\hline & true Qunte & true Totally & true Litte & dass predision \\
\hline pred Cuite & 6 & 1 & 0 & $85.71 \%$ \\
\hline pred Totally & 1 & 10 & 0 & $90.91 \%$ \\
\hline pred Litte & 0 & 0 & 2 & $100.00 \%$ \\
\hline dass recall & $85.71 \%$ & $90.91 \%$ & $100.00 \%$ & \\
\hline
\end{tabular}

Figure 15. Accuracy of Predictive Model 4

Table 4. Results of the linear regression (machine learning)

\begin{tabular}{|c|c|c|c|c|c|}
\hline Hypothesis & Description & $\begin{array}{c}\text { Linear } \\
\text { regression }\end{array}$ & Conclusion & t-Stat & p-Value \\
\hline $\mathrm{H} 1$ & $\begin{array}{l}\text { Assimilation of knowledge about the Simple } \\
\text { conditional structure through the FreeDFD } \\
\text { simulator, flipped classroom and YouTube } \\
\text { videos } \rightarrow \text { Grade of the first partial }\end{array}$ & $\begin{array}{c}y=0.668 x- \\
4.595\end{array}$ & $\begin{array}{l}\text { Accepted: } \\
0.668\end{array}$ & 1.668 & 0.133 \\
\hline $\mathrm{H} 2$ & $\begin{array}{l}\text { Assimilation of knowledge about the } \\
\text { Multiple conditional structure through the } \\
\text { FreeDFD simulator, flipped classroom and } \\
\text { YouTube videos } \rightarrow \text { Grade of the first partial }\end{array}$ & $\begin{array}{c}y=0.716 x- \\
5.145\end{array}$ & $\begin{array}{l}\text { Accepted: } \\
0.716\end{array}$ & 1.814 & 0.099 \\
\hline H3 & $\begin{array}{l}\text { Assimilation of knowledge about the For } \\
\text { iterative structure through the FreeDFD } \\
\text { simulator, flipped classroom and YouTube } \\
\text { videos } \rightarrow \text { Grade of the first partial }\end{array}$ & $\begin{array}{c}\mathrm{y}=0.735 \mathrm{x}- \\
5.412\end{array}$ & $\begin{array}{c}\text { Accepted: } \\
0.735\end{array}$ & 1.704 & 0.119 \\
\hline $\mathrm{H} 4$ & $\begin{array}{l}\text { Assimilation of knowledge about the While } \\
\text { iterative structure through the FreeDFD } \\
\text { simulator, flipped classroom and YouTube } \\
\text { videos } \rightarrow \text { Grade of the first partial }\end{array}$ & $\begin{array}{c}y=1.056 x- \\
8.700\end{array}$ & $\begin{array}{l}\text { Accepted: } \\
1.056\end{array}$ & 4.570 & 0.001 \\
\hline
\end{tabular}

The accuracy of Predictive Model 4 is $90.00 \%$ (See Figure 15).

Table 4 shows that the assimilation of knowledge by means of the FreeDFD simulator, flipped classroom and YouTube videos positively influences the grade of the first partial related to the Simple conditional structure (H1), Multiple conditional structure (H2) and While iterative structure (H4). 
R.-A. Salas-Rueda

Table 5. Assimilation of knowledge (efficiency)

\begin{tabular}{lcccc}
\hline & $\begin{array}{c}\text { Simple conditional } \\
\text { structure }\end{array}$ & $\begin{array}{c}\text { Multiple conditional } \\
\text { structure }\end{array}$ & $\begin{array}{c}\text { For iterative } \\
\text { structure }\end{array}$ & $\begin{array}{c}\text { While iterative } \\
\text { structure }\end{array}$ \\
\hline Totally & $7(35 \%)$ & $7(35 \%)$ & $8(40 \%)$ & $10(50 \%)$ \\
Quite & $12(60 \%)$ & $12(60 \%)$ & $10(50 \%)$ & $10(50 \%)$ \\
Regular & $1(5 \%)$ & $1(5 \%)$ & $2(10 \%)$ & $0(0 \%)$ \\
Little & $0(0 \%)$ & $0(0 \%)$ & $0(0 \%)$ & $0(0 \%)$ \\
Nothing & $0(0 \%)$ & $0(0 \%)$ & $0(0 \%)$ & $0(0 \%)$ \\
Total & $20(100 \%)$ & $20(100 \%)$ & $20(100 \%)$ & $20(100 \%)$ \\
\hline
\end{tabular}

Table 6. Correlation coefficient for the Assimilation of knowledge (efficiency)

\begin{tabular}{lcccc}
\hline & $\begin{array}{c}\text { Simple conditional } \\
\text { structure }\end{array}$ & $\begin{array}{c}\text { Multiple conditional } \\
\text { structure }\end{array}$ & $\begin{array}{c}\text { For iterative } \\
\text { structure }\end{array}$ & $\begin{array}{c}\text { While iterative } \\
\text { structure }\end{array}$ \\
\hline $\begin{array}{l}\text { Simple conditional } \\
\text { structure }\end{array}$ & 1 & & & \\
$\begin{array}{l}\text { Multiple conditional } \\
\text { structure }\end{array}$ & 0.83870968 & 1 & & \\
$\begin{array}{l}\text { For iterative structure } \\
\text { While iterative }\end{array}$ & 0.72929053 & 0.72929053 & 1 & 1 \\
structure & 0.71842121 & 0.53881591 & 0.78086881 & 1 \\
\hline
\end{tabular}

Table 7. Bloom Taxonomy: Memory Level

\begin{tabular}{lcccc}
\hline & $\begin{array}{c}\text { Simple conditional } \\
\text { structure }\end{array}$ & $\begin{array}{c}\text { Multiple conditional } \\
\text { structure }\end{array}$ & $\begin{array}{c}\text { For iterative } \\
\text { structure }\end{array}$ & $\begin{array}{c}\text { While iterative } \\
\text { structure }\end{array}$ \\
\hline Totally & $8(40 \%)$ & $9(45 \%)$ & $8(40 \%)$ & $8(40 \%)$ \\
Quite & $8(40 \%)$ & $8(40 \%)$ & $11(55 \%)$ & $10(50 \%)$ \\
Regular & $4(20 \%)$ & $3(15 \%)$ & $1(5 \%)$ & $2(10 \%)$ \\
Little & $0(0 \%)$ & $0(0 \%)$ & $0(0 \%)$ & $0(0 \%)$ \\
Nothing & $0(0 \%)$ & $0(0 \%)$ & $0(0 \%)$ & $0(0 \%)$ \\
Total & $20(100 \%)$ & $20(100 \%)$ & $20(100 \%)$ & $20(100 \%)$ \\
\hline
\end{tabular}

\section{FreeDFD Simulator, Flipped Classroom and YouTube Videos}

The FreeDFD simulator allows linking the contents of the Logical of Predicates Unit with the field of computer science (conditional and iterations structures). According to the students $(\mathrm{n}=12,60 \%)$, the FreeDFD simulator, flipped classroom and YouTube videos quite facilitate the assimilation of knowledge about the topics on the Logic of the predicates through the Simple and Multiple conditional structures. Also, Table 5 shows that the majority of the students $(n=10,50 \%)$ are in the Quite category for the iterative structures.

Table 6 shows that the dimensions of the variable Assimilation of knowledge (efficiency) has a significant relationship because the values obtained in the correlation coefficient are greater than 0.53 .

In this research, the variable Technical quality is integrated by the following dimensions related to Bloom's Taxonomy: Memory, Understanding and Application.

The students of the Bachelor in Business Management and Information Technology believe that the FreeDFD simulator, flipped classroom and YouTube videos totally and quite facilitate the identification of the conditional and iteration structures (Memory level) during the educational process (See Table 7).

Table 8 shows that the most significant relationship of correlation coefficient (0.88732748) is located between the dimensions for iterative structure and simple conditional structure. 
Online Journal of Communication and Media Technologies, 2018

Table 8. Correlation coefficient for the Memory level

Simple conditional Multiple conditional For iterative While iterative structure structure structure structure

Simple conditional

structure

Multiple conditional

structure

For iterative structure

While iterative structure
1

0.82332931

0.88732748 0.70956629
1

0.84416697 0.78727323
1 0.80505293

Table 9. Bloom's taxonomy: Understanding level

\begin{tabular}{lcccc}
\hline & $\begin{array}{c}\text { Simple conditional } \\
\text { structure }\end{array}$ & $\begin{array}{c}\text { Multiple conditional } \\
\text { structure }\end{array}$ & $\begin{array}{c}\text { For iterative } \\
\text { structure }\end{array}$ & $\begin{array}{c}\text { While iterative } \\
\text { structure }\end{array}$ \\
\hline Totally & $9(45 \%)$ & $8(40 \%)$ & $7(35 \%)$ & $9(45 \%)$ \\
Quite & $8(40 \%)$ & $10(50 \%)$ & $10(50 \%)$ & $9(45 \%)$ \\
Regular & $3(15 \%)$ & $2(10 \%)$ & $3(15 \%)$ & $2(10 \%)$ \\
Little & $0(0 \%)$ & $0(0 \%)$ & $0(0 \%)$ & $0(0 \%)$ \\
Nothing & $0(0 \%)$ & $0(0 \%)$ & $0(0 \%)$ & $0(0 \%)$ \\
Total & $20(100 \%)$ & $20(100 \%)$ & $20(100 \%)$ & $20(100 \%)$ \\
\hline
\end{tabular}

Table 10. Correlation coefficient for the Understanding level

\begin{tabular}{|c|c|c|c|c|}
\hline & $\begin{array}{c}\text { Simple conditional } \\
\text { structure }\end{array}$ & $\begin{array}{c}\text { Multiple conditional } \\
\text { structure }\end{array}$ & $\begin{array}{c}\text { For iterative } \\
\text { structure }\end{array}$ & $\begin{array}{c}\text { While iterative } \\
\text { structure }\end{array}$ \\
\hline Simple conditional structure & 1 & & & \\
\hline $\begin{array}{l}\text { Multiple conditional } \\
\text { structure }\end{array}$ & 0.78727323 & 1 & & \\
\hline For iterative structure & 0.80519414 & 0.89803603 & 1 & \\
\hline While iterative structure & 0.73886645 & 0.82406052 & 0.85691278 & 1 \\
\hline
\end{tabular}

Table 11. Bloom Taxonomy: Application Level

\begin{tabular}{lcccc}
\hline & $\begin{array}{c}\text { Simple conditional } \\
\text { structure }\end{array}$ & $\begin{array}{c}\text { Multiple conditional } \\
\text { structure }\end{array}$ & $\begin{array}{c}\text { For iterative } \\
\text { structure }\end{array}$ & $\begin{array}{c}\text { While iterative } \\
\text { structure }\end{array}$ \\
\hline Totally & $9(45 \%)$ & $8(40 \%)$ & $9(45 \%)$ & $11(55 \%)$ \\
Quite & $7(35 \%)$ & $10(50 \%)$ & $8(40 \%)$ & $7(35 \%)$ \\
Regular & $3(15 \%)$ & $1(5 \%)$ & $2(10 \%)$ & $0(0 \%)$ \\
Little & $1(5 \%)$ & $1(5 \%)$ & $1(5 \%)$ & $2(10 \%)$ \\
Nothing & $0(0 \%)$ & $0(0 \%)$ & $0(0 \%)$ & $0(0 \%)$ \\
Total & $20(100 \%)$ & $20(100 \%)$ & $20(100 \%)$ & $20(100 \%)$ \\
\hline
\end{tabular}

For the level of understanding, the students consider that the FreeDFD simulator, flipped classroom and YouTube videos totally facilitate the recognition of the Simple conditional structure $(n=9,45 \%)$, Multiple conditional structure $(n=8,40 \%)$, For iterative structure $(n=7,35 \%)$ and While iterative structure $(n=9,45 \%)$. Table 9 shows that none of the participants is in the Little and Nothing categories.

Table 10 shows that all correlation coefficients have a value greater than 0.73 for the understanding level of Bloom's Taxonomy.

Regarding the application level (Bloom Taxonomy), respondents point out that the FreeDFD simulator, flipped classroom and YouTube videos totally facilitate the use of the Simple conditional structure $(n=9,45 \%)$ and Multiple conditional structure $(n=8,40 \%)$. Table 11 shows that the majority of students are in the Totally category for the iterative structures: for $(n=9,45 \%)$ and while $(n=11,55 \%)$.

All the correlation coefficients on the Application Level are greater than the value 0.73 (See Table 12). The most significant relationship is presented between the dimensions of the iterative structures (0.8783458). 
Table 12. Correlation coefficient for the Application level

\begin{tabular}{lcccc}
\hline & $\begin{array}{c}\text { Simple conditional Multiple conditional For iterative } \\
\text { structure }\end{array}$ & $\begin{array}{c}\text { While iterative } \\
\text { structure }\end{array}$ & $\begin{array}{c}\text { structure } \\
\text { structure }\end{array}$ \\
\hline $\begin{array}{l}\text { Simple conditional } \\
\text { structure }\end{array}$ & 1 & & & \\
Multiple conditional & 0.82309878 & 1 & & \\
structure & 0.76088591 & 0.76706883 & 1 & \\
For iterative structure & 0.73137009 & 0.80674186 & 0.8783458 & 1 \\
While iterative structure & & & & \\
\hline
\end{tabular}

\section{Perceptions of Students}

This research analyzes the aspect of Quality of service by means of the Teachinglearning process, Technological ability and Mathematical ability dimensions. The students of the Computational Mathematics course believe that continuous improvement facilitates the creation of an efficient teaching-learning process through the FreeDFD simulator, flipped classroom and YouTube videos:

"Yes, you check content on YouTube to solve the exercises" (Student 13, Female, 19 years old).

"Yes, because the videos explain well and it's simple" (Student 17, Male, 20 years old).

"Yes, videos are a great option to start using the application" (Student 18, Female, 19 years old).

Even, Juran's methodology facilitates the construction of visual, creative and useful spaces for learning and teaching:

"Yes, it's more visual" (Student 2, Male, 19 years old).

"Yes, because it is a more creative way to learn" (Student 4, Female, 19 years old).

"Yes, because the subject is more visual" (Student 15, Female, 19 years old).

According to the students, the FreeDFD simulator, flipped classroom and YouTube videos facilitate the development of mathematical skills:

"Facilitates the mathematical process" (Student 1, Male, 19 years old).

"Yes, it's more practical" (Student 2, Male, 19 years old).

"Yes, an explanation is presented step by step" (Student 15, Female, 19 years old).

In the same way, the use of the Juran's methodology in the Logical of Predicates Unit allows the development of technological skills:

"Yes, when using the programs" (Student 13, Female, 19 years old).

"Yes, because you must know how to use these tools" (Student 17, Male, 20 years old).

"Yes, because the computer is used" (Student 20, Male, 20 years old). 
Online Journal of Communication and Media Technologies, 2018

This study analyzes customer satisfaction through the Utility, Benefits and Need dimensions. The participants are satisfied to use the FreeDFD simulator, flipped classroom and YouTube videos during the Logical of Predicates Unit:

"Yes, they help to understand better" (Student 5, Male, 22 years old).

"A lot, we learn in different ways" (Student 11, Male, 20 years old).

"Yes, because it is a simple way to learn" (Student 17, Male, 20 years old).

Also, the students emphasize that the use of technology allows the verification of the exercises on the logic of predicates:

"Yes, they are good support tools" (Student 13, Female, 19 years old).

"Yes, you can check the results" (Student 16, Female, 19 years old).

"Yes, they are a guide" (Student 18, Female, 19 years old).

The students of the Degree in Business Management and Information Technology consider that the benefit over the use of technology in the Logical of Predicates Unit is the facility for learning:

"Understand the subject better" (Student 5, Male, 22 years old).

“They help to exemplify class contents" (Student 13, Female, 19 years old).

"Acquire new knowledge in the area of technology" (Student 18, Female, 19 years old).

Likewise, students think that the incorporation of ICT into the educational process is necessary:

"Yes, to automate the process" (Student 1, Male, 19 years old).

"Yes, because it is practical" (Student 15, Female, 19 years old).

"Yes, because you can understand the subject in another way" (Student 20, Male, 20 years old).

\section{DISCUSSION}

Juran's methodology on continuous improvement allows building innovative and creative spaces for teaching and learning. In particular, this mixed research proposes the use of the FreeDFD simulator, flipped classroom and YouTube videos to innovate school activities in the Logical of Predicates Unit.

This research confirms the findings of various authors (e.g., García, Quispe and Ráez, 2003) on the importance of creating efficient processes to achieve customer satisfaction. In particular, the students of the Degree in Business Management and Information Technology consider that the use of technology facilitates the creation of efficient processes for teaching and learning.

For example, the students of the Computational Mathematics course point out that the use of the FreeDFD simulator, flipped classroom and YouTube videos allow reaching the levels of Bloom's Taxonomy: memory, understanding and application. Likewise, the 
participants are satisfied to use these digital tools because they allow verifying the exercises on the quantifiers and the demonstration by induction.

Data mining allows identifying the aspects that influence the assimilation of knowledge about the Conditional and Iteractive structures. In particular, the data science (decision trees technique) allows describing the following prediction models:

- Predictive Model 1: Assimilation of knowledge model about Simple conditional structure

- Predictive Model 2: Assimilation of knowledge model about Multiple conditional structure

- Predictive Model 3: Assimilation of knowledge model about For iterative structure

- Predictive Model 4: Assimilation of knowledge model about While iterative structure

This study confirms the ideas of several authors (e.g., Blau \& Shamir, 2017; Chen, Wang, Kinshuk \& Chen, 2014) about the role of the flipped classroom to improve the educational process. In particular, the students of the Computational Mathematics course mention that the FreeDFD simulator, flipped classroom and YouTube videos allow the development of skills (mathematics and technology) and the assimilation of knowledge.

The incorporation of ICT in school activities implies the planning, organization and implementation of substantial changes in the traditional educational model (Salas 2015; Vázquez, López, \& Jaén, 2017). In particular, this research proposes the realization of various teaching-learning activities before (see YouTube videos), during (exercises on the Logic of predicates) and after (realization of laboratory practice through FreeDFD simulator) of the session.

In addition, the results of the linear regression (automatic machine learning with $50 \%$ of training and $50 \%$ of evaluation) indicate that the FreeDFD simulator, flipped classroom and YouTube videos facilitate the teaching-learning process in the Logical of Predicates Unit. Finally, universities face the great challenge of achieving educational quality (Ocampo \& Reyna, 2016).

\section{CONCLUSION}

Juran's methodology on continuous improvement allows the construction of innovative and creative spaces for learning, that is, the identification of clients, establishment of needs, development of the service and transfer of the process are fundamental elements to improve the assimilation of knowledge and improvement of skills in the students.

In particular, the incorporation of technology in the Computational Mathematics course facilitated the linking and application of the theoretical contents on Categorical Propositions (universal and existential quantifiers) and Reasoning (demonstration by induction) in the field of computer science.

To achieve continuous improvement in the educational context, this research used the FreeDFD simulator, flipped classroom and YouTube videos in the Logical of Predicates Unit. Also, this study recommends the Juran's methodology to create new and innovative learning spaces that meet the needs and demands of students in the XXI Century.

Data mining is a valuable tool to identify the relationships between variables. In particular, this study identified various predictive models of Assimilation of knowledge through the decision tree technique. 
The limitations of this study are the use of videos and FreeDFD simulator. Therefore, future research can analyze the incorporation of various information and communication tools such as social networks or augmented reality. Finally, teachers can transform the educational environment through Continuous Improvement and Technology in order to develop competencies in the students.

\section{REFERENCES}

Alexander, J. A., Weiner, B. J., Shortell, S. M., \& Baker, L. (2007). Does Quality Improvement Implementation Affect Hospital Quality of Care? Journal Hospital Topics, 85(2), 3-12. https://doi.org/10.3200/HTPS.85.2.3-12

Blau, I., \& Shamir Inbal, T. (2017). Re-designed flipped learning model in an academic course: The role of co-creation and co-regulation. Computers \& Education, 115, 69-81. https://doi.org/10.1016/j.compedu.2017.07.014

Bryant, M. (2013). International Accreditations as Drivers of Business School Quality Improvement. Journal of Teaching in International Business, 24(3), 155-167. Retrieved from https://doi.org/10.1080/08975930.2013.860345

Burgi, J., \& Peralta Rojas, M. (2011). El concepto de calidad educativa en las investigaciones sobre educación en chile (2000-2008). Revista Iberoamericana sobre Calidad, Eficacia y Cambio en Educación, 9, 72-93. Retrieved from http://www.rinace.net/reice/numeros/arts/vol9num3/art4.pdf

Cantú Delgado, H. (2001). Desarrollo de una cultura de calidad. Mexico: McGraw-Hill.

Carreño, A. (2009). Medición de la calidad, la eficiencia y la productividad en hospitales públicos de tercer nivel de atención en Bogotá, 2008. Universidad y Empresa, 17, 203222. Retrieved from http://revistas.urosario.edu.co/index.php/empresa/article/view/ 1089

Chang, P. C. (2017). On quality improvement of a multistate production network with service level consideration. International Journal of Systems Science: Operations \& Logistic, 4(2), 135-144. https://doi.org/10.1080/23302674.2015.1116636

Chen, Y.,Wang, Y., Kinshuk, A., \& Chen, N. S. (2014). Is FLIP enough? Or should we use the FLIPPED model instead? Computers \& Education, 79, 16-27. https://doi.org/10. 1016/j.compedu.2014.07.004

Colmenares Gilly, L. A. (2010). Proceso de mejora y cambio en una escuela venezolana. Revista Iberoamericana sobre Calidad, Eficacia y Cambio en Educación, 8, 154-168. Retrieved from http://www.rinace.net/reice/numeros/arts/vol8num5/art12.pdf

Fernández Ortiz, R., González Menorca, L., Fernández Losa, N., \& Segura Andollo, M. J. (2010). Calidad universitaria: expectativas de los estudiantes recién incorporados. Revista Nacional de Administración, 1(2), 17-30. https://doi.org/10.22458/rna.v1i2. 331

García, M., Quispe, C., \& Ráez, L. (2003). Mejora continua de la calidad en los procesos. Industrial Data, 6(1), 89-94. https://doi.org/10.15381/idata.v6i1.5992

Halder, I., Halder, S., \& Guha, A. (2015). Educational Use of Mobile Phones by Undergraduate Students: An Indian Perspective. Online Journal of Communication and Media Technologies, 5(4), 64-76. Retrieved from http://www.ojcmt.net/article/educational-use-of-mobile-phones-by-undergraduatestudents-an-indian-perspective

He, Y., Xu, Q., Xu, B., \& Wu, P. (2016). Supply chain coordination in quality improvement with reference effects. Journal of the Operational Research Society, 67(9), 1158-1168. https://doi.org/10.1057/jors.2016.10 
Lizarzaburu Bolaños, E. R. (2016). La gestión de la calidad en Perú: un estudio de la norma ISO 9001, sus beneficios y los principales cambios en la versión 2015 . Universidad y Empresa, 18(30), 33-54. https://doi.org/10.12804/rev.univ.empresa.30. 2016.02

Maffini, C. S. \& Toth, P. L. (2017). Quality Improvement in University Counseling Centers. Journal of College Student Psychotherapy, 31(1), 43-58. https://doi.org/10.1080/87568225.2016.1254000

Mamghani, N. K., Mostowfi, S., \& Khorram, M. (2016). Designing an Educational Aid Tool to Learning Waste Separation for 5-7 Years Old Children. Online Journal of Communication and Media Technologies, 6(1), 23-34. Retrieved from http://www.ojcmt.net/article/designing-an-educational-aid-tool-to-learning-wasteseparation-for-5-7-years-old-children

Ocampo Herrera, D. M. \& Reyna Pineda, S. F. (2016). El liderazgo escolar: implicaciones en la calidad de las organizaciones educativas del contexto actual en México. Revista Nacional de Administración, 7(1), 107-117. https://doi.org/10.22458/rna.v7i1.1519

Peralta, C. A. (2016). Adecuación de la Planeación Didáctica como Herramienta Docente en un Modelo Universitario Orientado al Aprendizaje. Revista Iberoamericana sobre Calidad, Eficacia y Cambio en Educación, 14(3), 109-130. https://doi.org/10.15366/reice2016.14.3.006

Salas Rueda, R. A. (2015). Uso de la infografía en los entornos virtuales personalizados para el proceso de enseñanza-aprendizaje sobre el álgebra booleana. Revista de Comunicación Vivat Academia, 130, 37-47. https://doi.org/10.15178/va.2015.130.6474

Salas Rueda, R. A. (2018). Uso del servicio en la nube GeoGebra durante el proceso enseñanza-aprendizaje sobre las matemáticas. Revista iberoamericana para la investigación y el desarrollo educativo, 8, 23-52. https://doi.org/10.23913/ride.v8i16. 331

Salas Rueda, R. A., \& Salas Silis, J. A. (2018). Simulador Logic.ly ¿Herramienta tecnológica para facilitar el proceso enseñanza-aprendizaje sobre las Matemáticas? Revista Dilemas Contemporáneos: Educación, Política y Valores, 5(3), 1-25.

Salas Rueda, R. A., \& Vázquez Estupiñán, J. J. (2018). Aplicación en la nube Lucidchart: ¿herramienta necesaria para la innovación del proceso educativo en el siglo XXI? Revista de Comunicación de la SEECI, 44, 115-126. https://doi.org/10.15198/seeci. 2017.44.115-126

Salas Rueda, R. A., Vázquez Estupiñán, J. J., \& Lugo García, J. L. (2016). Uso del avatar en el proceso de enseñanza aprendizaje sobre las aplicaciones de las derivadas. Revista de Comunicación de la SEECI, 39,71-84. https://doi.org/10.15198/seeci.2016. 39.72-88

Salazar Yépez, W., \& Cabrera Vallejo, M. (2016). Diagnóstico de la calidad de servicio, en la atención al cliente, en la Universidad Nacional de Chimborazo Ecuador. Industrial data, 19(2), 13-20. https://doi.org/10.15381/idata.v19i2.12811

Tartaglia, K. M., \& Walker, C. (2015). Effectiveness of a quality improvement curriculum for medical students. Journal Medical Education Online, 20(1), 1-6. https://doi.org/10.3402/meo.v20.27133

Treagust, D. F., Won, M., Petersen, J., \& Wynne, G. (2015). Science Teacher Education in Australia: Initiatives and Challenges to Improve the Quality of Teaching. Journal of Science Teacher Education, 26(1), 81-98. https://doi.org/10.1007/s10972-014-9410-3 
Vasquez Rodriguez, J. A. (2016). El manual maestro de procesos y procedimientos, un paso hacia la gestión de la calidad: el caso del Consejo Nacional de Vialidad. Revista Nacional de Administración, 7(2), 121-141. https://doi.org/10.22458/rna.v7i2.1516

Vázquez Cano, E., López Meneses, E., \& Jaén Martínez, A. (2017), The Group e-portfolio to improve Teaching-Learning Process at University. Journal of e-Learning and Knowledge Society, 13(2), 65-76. https://doi.org/10.20368/1971-8829/1221

Wondemtegegn, S. A. (2018). University Students' Perception and Utilization of Technology for Learning: The Case of Haramaya University. Online Journal of Communication and Media Technologies, 8(1), 130-149. Retrieved from http://www.ojcmt.net/article/university-students-perception-and-utilization-oftechnology-for-learning-the-case-of-haramaya

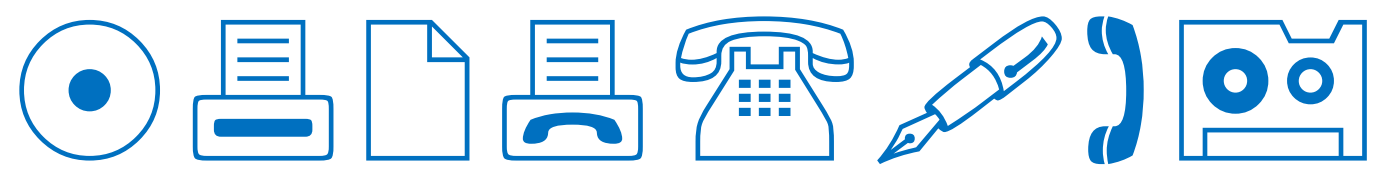

